Research Article

\title{
Exotic Epiphytes on Tree Ferns in Cibodas Botanical Gardens: The Importance of Light Preferences and Host Characteristics
}

\author{
Decky Indrawan Junaedi *, Taufikurrahman Nasution \\ Cibodas Botanical Gardens, Indonesian Institute of Sciences (LIPI), Cianjur 43253, Indonesia
}

Article history:

Submission March 2018

Revised August 2018

Accepted August 2018

*Corresponding author:

E-mail: deqee82@gmail.com

\begin{abstract}
The study of exotic epiphytes on tree ferns is relatively scarce. Biological invasion of exotic epiphytes may imply negative consequences to native epiphytes and tree ferns, which are important components in tropical mountainous rainforest ecosystems. This study surveyed exotic epiphytes on tree ferns in Cibodas Botanical Gardens (CBG) and adjacent forests next to CBG. The objectives of this study are: a) to conduct inventory study of exotic epiphyte species on tree ferns, b) to examine how different these exotic epiphytes from each other based on their microclimate preferences, c) to conduct invasive risk assessment of those exotic epiphytes, and d) to model the effect of environmental factors and host (tree ferns) characteristics to the occurrence of exotic epiphytes on tree ferns. We conducted multi-dimensional analysis to examine how different these exotic epiphytes based on their micro-climate parameters. We used Weed Risk Assessment (WRA) framework to estimate the invasion risks of surveyed exotic epiphytes. We performed Bayesian logistic regression to test the correlation between environmental and host characteristics and the occurrence probability of exotics epiphytes on tree ferns. We found 13 exotic epiphyte species on two native tree ferns species (Cyathea junghuhniana and Cyathea contaminans). Multidimensional analysis showed that Axonopus compressus is very different from other exotic epiphytes due to its environmental preferences. Ageratina riparia and Clidemia hirta were exotic epiphytes with the highest invasion risks. Therefore, we suggested that $A$. riparia and $C$. hirta are more likely to become invasive and may contribute significant impacts to native ecosystems. Lastly, the presence of Austroeupatorium inulaefolium as exotic epiphytes in tree ferns negatively correlated with the host height. Further study is needed to incorporate biological traits of the exotic epiphytes and more specific environmental parameters such as light chromatic quality in to the exotic epiphyte occurrence model. This study provides evidence for the existences of exotic epiphytes on tree ferns. The result of this study may also indicate that host characteristics and micro-climate factors could play important roles to inhibit the occurrence of exotic epiphytes on tree ferns.
\end{abstract}

Keywords: Invasive plant, ecology, conservation, logistic regression, Cibodas Botanical Gardens, epiphyte, tree fern, exotic epiphyte

\section{Introduction}

Invasive species is an important global ecological issue. Even though the definite impact of invasive species is still questionable [1], invasive species assert potential threat to plant extinction [2]. The negative impact of invasive species may also be intensified by the global environmental change [3]. From the ecological perspective, invasive species may eliminate several roles and ecolo- gical processes such as: water balance shifts and nutrient cycle [4]. Therefore, invasive species should be controlled and if possible, should be eradicated to minimize their negative impacts [5].

Most plant invasion studies are on terrestrial plants species rather than epiphyte species because exotic epiphytes assumed to have lower invasion risks than terrestrial exotic plants [6]. On the other hand, the study of exotic epiphyte species on tree 
ferns is also scarce [7], even though epiphyte plays an important role in maintaining microhabitat under the canopy shade [8]. Several endangered plants species are epiphytes. Thus, alteration of epiphyte communities by exotic epiphytes occurrence and invasion will alter ecological processes and roles in the lower layer of tropical forests.

Tree ferns are part of tropical forest ecosystems and are hosts for many epiphyte species. The study of epiphytes and tree ferns as its host showed that tree ferns species and the morphology of their trunk influenced epiphytic plant communities [9]. The root mantles on trunk of tree ferns provided a more favourable microhabitat for epiphytic plant growth [10]. Furthermore, substrate depth and water holding capacity of tree ferns root mantles are also important factors for epiphyte occurrence [11]. The study of exotic epiphytes in tree ferns are crucial because this kind of studies are relatively scarce. Exotic epiphytes studies will provide information for more comprehensive exotic species management, particularly in the tropical ecosystems. Epiphytes are a crucial component of tropical rainforest which contain biodiversity and local climate of those ecosystems.

The objectives of this study are: a) to conduct inventory study of exotic epiphyte species on tree ferns, b) to examine how different these exotic epiphytes from each other based on their micro-climate preferences, c) to conduct invasive risk assessment of those exotic epiphytes, and d) to model the effect of environmental factors and host (tree ferns) characteristics to the existence of exotic epiphytes on tree ferns. Comprehensive understanding of tropical exotic epiphytes will contribute to rigorous information about invasion ecology in tropical ecosystems, particularly for tropical invasive species management purposes.

\section{Material and Methods Location}

The study conducted in Cibodas Botanical Gardens (CBG) area and adjacent native remnant forests that located inside the CBG area. CBG area was situated on 1,300 - 1,425 meters above sea level (masl), next to Gede-Pangrango National Park (S 0644.515', E $107^{\circ} 00.290^{\prime}$ ). The annual rainfall in CBG area was approximately around $2,950 \mathrm{~mm} /$ year, average temperature was $20^{\circ} \mathrm{C}$ and relative air humidity was around $80 \%$ [12].
CBG covered an area of approximately 85 hectares, including more than 8 hectares secondary remnant forests area.

\section{Sampling and analysis}

Thirty Cyathea contaminans and thirty $C y$ athea junghuhniana were sampled from gardens and remnant forests of CBG. We did not find other tree fern species in the study site. Dicksonia blumei exist in different elevation (beyond 1,500 masl) from this ecosystem $[13,14]$. These sampled tree ferns were grown naturally in CBG area (in garden area and remnant forest area) and are not intentionally planted. Thus, we did not include tree ferns of CBG gardens collections.

We measured light intensity (lux), air temperature $\left({ }^{\circ} \mathrm{C}\right)$, and relative air humidity (\%) as microclimate environmental parameters. These microclimate variables were measured at different times (morning, midday, and afternoon) and then averaged. These data measured from March to May, during the transition period between rainy and dry season. Height and diameter breast height (dbh) were measured as host (tree fern) characteristics in this study. Tree fern's height measured from the base of the trunks to the tip of the crozier (the bud of the frond, young "leaf" of tree fern). All exotic epiphytes that found on tree ferns were recorded and the number of total individual exotic epiphytes for every species were counted. The term exotic refers to geographical boundaries, which mean that epiphytes that originated from Malesian regions but are from outside Indonesia region were defined as exotic. The native epiphyte species also counted and recorded for Multi-Dimensional Scaling (MDS) analysis purposes. The epiphytes were excluded from the sampling if the main roots are not originated from the bark of the tree fern.

The ecological habitat (micro-climate) datasets in every sampled tree fern were recorded. These data consist of: light intensity (lux, measured using Digital Lux meter LX-10108), air temperature $\left({ }^{\circ} \mathrm{C}\right)$ and air relative humidity $(\%$, measured using pocket weather meter Kestrel 3000). Multi-dimensional scaling (MDS) analysis was conducted using XLSTAT (add-on in Microsoft Excel) to analyse how different are these exotic epiphytes from each other, based on measured ecological / habitat variables.

All exotic epiphytes were assessed using 
Weed Risk Assessment (WRA) system [15] to predict and estimate the potential risk or likelihood of those exotic species, which provide an indication whether these exotic epiphytes will become invasive in the future or not. The assessment also refers to the risk that may be carried as the invasion consequences. Therefore, the assessment result will indicate which exotic epiphytes should be prioritized to be managed. The exotic epiphyte invasive risk reflected from the WRA assessment score result. The negative WRA score means that the exotic has a low risk of invasion and allowed to exist. The WRA score from 0 to 6 indicate that the species need evaluation further to be considered as accepted exotic species or rejected (high risk). The WRA score more than 6 means that the exotic species will be likely to become invasive and carrying potential impacts to native ecosystem [15].

A Bayesian logistic regression analysis conducted for the abundant exotic epiphytes. We omit the scarce exotic epiphytes from this analysis due to a limited number of samples. This analysis conducted to test whether the presence-absence proportion of exotic epiphytes on tree ferns associated with the explanatory variables (micro-climate and host parameters). The logistic regression conducted by using the presence-absence data as the categoric dependent variable by stating 1 as present and 0 as absent, and explanatory variables as independent variables. The explanatory variables included in the model were: micro-climate factors (light intensity, air relative humidity, and air temperature) and tree ferns (host) characteristics (height and dbh). The statistical model of the logistic regression following model 1 :

$$
T(x)=e^{j(x)} /\left(1+e^{j(x)}\right)
$$

Note:

$T(x)=$ the proportion of presence/absence of exotic epiphytes on sampled tree ferns

$j(x)=\alpha+\beta_{1} x_{1}+\beta_{2} x_{2}+\beta_{3} x_{3}+\beta_{4} x_{4}+\beta_{5} x_{5}+\varepsilon_{i}$. The $x_{1}$ $x_{2}, x_{3}, x_{4}$, and $x_{5}$ refers to light intensity (lux), air relative humidity (\%), air temperature (0C), tree fern's height $(\mathrm{cm})$ and tree fern's dbh $(\mathrm{cm})$ respectively

The Bayesian logistic regression calculation performed in R [16] using JAGS [17] with package jagsUI [18]. We provide JAGS code for the analysis in Supplementary file 1. We ran 3 MCMC chains and drew 10,000 samples per chain, omitting the first 5,000 iterations as a burn-in.

\section{Results and Discussion}

We found totally 13 exotic epiphyte species from two tree fern species in CBG area (Table 1). Six species only found in $C$. contaminans. Three species only existed in $C$. junghuhniana. Four exotic epiphytes species recorded from both tree ferns species. The exotic epiphyte species recorded in this study are from seven families: Acanthaceae, Compositae, Fabaceae, Marantaceae, Melastomataceae, Poaceae and Solanaceae.

Most exotic epiphytes recorded from C. contaminans were Compositae species (S. nodiflora, A. conyzoides, B. sordida, A. inulaefolium, and A. riparia). This might be caused by the fact that most of C. contaminans in CBG are in the fully sunlight areas. In contrast, there was no Compositae exotic epiphyte species recorded from $C$. junghuhniana because this tree fern species was found in the shaded area in CBG, mostly inside the remnant forest area. Apparently, light intensity is a key factor that may determine the existence of exotic epiphyte on tree ferns. Thus, the occurrence of exotic epiphytes may be conditional to the ecological preferences of host tree ferns.

The epiphytes occurred on C. contaminans were more abundant than on C. junghuhniana and two reasons may explain this finding. First, the size of $C$. contaminans' trunk was relatively bigger than $C$. junghuhniana. The bigger the trunk size, the wider the trunks surface can contain epiphytes [19]. Secondly, since most of the exotics were belong to Compositae and C. junghuhniana preferred shaded environment (smaller light intensity, Table 2), most of these exotics supported better on C. contaminans' trunks than C. junghuhniana. Most Compositae species preferred high light intensity and grow not very well under some extent of shadings [20].

However, exotic epiphyte density per meter square of trunk surface on $C$. junghuhniana is bigger than $C$. contaminans. The average density of exotic epiphyte is 1 individuals / $\mathrm{m}^{2}$ and 1 individuals $/ \mathrm{m}^{2}$ for on C. junghuhniana and C. contaminans respectively (Table 2). The possible explanation for this figure is that $C$. jughuhniana exists in more humid area than $C$. contaminans. Humidity is an important factor for epiphyte diversity and life supports [7, 21]. 
Table 1. Exotic epiphyte species recorded from two host tree fern species: Cyathea contaminans and Cyathea junghuhniana in Cibodas Botanical Gardens (CBG) area. The numbers in the host tree fern columns refers to the number of exotic epiphytes individuals found from those corresponding tree ferns (host). WRA score refers to the risk assessment result following proposed method by Pheloung et al. (1999) [15]. Scoring detail provided in Supplementary file 2.

\begin{tabular}{|c|c|c|c|c|c|}
\hline \multirow[b]{2}{*}{ No } & \multirow[b]{2}{*}{ Exotic Epiphyte Species } & \multirow[b]{2}{*}{ Families } & \multirow[b]{2}{*}{$\begin{array}{l}\text { WRA } \\
\text { score }\end{array}$} & \multicolumn{2}{|c|}{ Host Tree Ferns } \\
\hline & & & & $\begin{array}{c}\text { Cyathea } \\
\text { contaminans }\end{array}$ & $\begin{array}{c}\text { Cyathea } \\
\text { junghuhniana }\end{array}$ \\
\hline 1. & Maranta lietzei & & & & \\
\hline & $\begin{array}{l}\text { (E.Morren) C.H.Nelson, Sutherl. \& } \\
\text { Fern.Casas }\end{array}$ & Marantaceae & 10 & - & 1 \\
\hline 2. & Solanum ferox Scop. & Solanaceae & 15 & - & 1 \\
\hline 3. & $\begin{array}{l}\text { Strobilanthes hamiltoniana } \\
\text { (Steud.) Bosser \& Heine }\end{array}$ & Acanthaceae & 9 & - & 1 \\
\hline 4. & $\begin{array}{l}\text { Axonopus compressus (Sw.) } \\
\text { P.Beauv. }\end{array}$ & Poaceae & 11 & 5 & - \\
\hline 5. & Synedrella nodiflora (L.) Gaertn. & Compositae & 8 & 2 & - \\
\hline 6. & Ageratum conyzoides (L.) L. & Compositae & 8 & 1 & - \\
\hline 7. & $\begin{array}{l}\text { Bartlettina sordida (Less.) } \\
\text { R.M.King\&H.Rob. }\end{array}$ & Compositae & 9 & 1 & - \\
\hline 8. & Calliandra calothyrsus Meisn. & Fabaceae & 13 & 1 & - \\
\hline 9. & Pennisetum sp. & Poaceae & 16 & 1 & - \\
\hline 10. & $\begin{array}{l}\text { Ageratina riparia (Regel) R.M.King } \\
\text { \& H.Rob. }\end{array}$ & Compositae & 21 & 24 & 12 \\
\hline 11. & $\begin{array}{l}\text { Austroeupatorium inulaefolium } \\
\text { (Kunth) R.M.King\&H.Rob. }\end{array}$ & Compositae & 11 & 4 & 5 \\
\hline 12. & Cestrum aurantiacum Lindl. & Solanaceae & 12 & 1 & 1 \\
\hline 13. & Clidemia hirta (L.) D. Don & Melastomataceae & 17 & 11 & 12 \\
\hline
\end{tabular}

Table 2. The average value of selected variables analyzed in the study from totally 60 sampling (30 Cyathea contaminans and 30 Cyathea junghuhniana).

\begin{tabular}{|c|c|c|c|c|}
\hline \multirow{3}{*}{ Variables } & \multicolumn{4}{|c|}{ Host tree fern species } \\
\hline & \multicolumn{2}{|c|}{ Cyathea contaminans } & \multicolumn{2}{|c|}{ Cyathea junghuhniana } \\
\hline & $\begin{array}{c}\text { Native } \\
\text { epiphytes }\end{array}$ & $\begin{array}{c}\text { Exotic } \\
\text { epiphytes }\end{array}$ & $\begin{array}{c}\text { Native } \\
\text { epiphytes }\end{array}$ & $\begin{array}{c}\text { Exotic } \\
\text { epiphytes }\end{array}$ \\
\hline Number of epiphyte species & 9 & 2 & 10 & 1 \\
\hline Epiphyte abundance & 40 & 20 & 3 & 5 \\
\hline Epiphyte density (ED) & 3 & 1 & 10 & 1 \\
\hline Relative epiphyte density (ED/TD) & 1 & 0 & 1 & 0 \\
\hline Total epiphyte species & \multicolumn{2}{|c|}{10} & \multicolumn{2}{|c|}{11} \\
\hline Total epiphyte abundance & \multicolumn{2}{|c|}{61} & \multicolumn{2}{|c|}{41} \\
\hline Trunk surface area $\left(\mathrm{m}^{2}\right)$ & \multicolumn{2}{|c|}{29.96} & \multicolumn{2}{|c|}{5.49} \\
\hline Total epiphyte density (TD) & \multicolumn{2}{|c|}{4} & \multicolumn{2}{|c|}{11} \\
\hline Trunks height (cm) & \multicolumn{2}{|c|}{727.63} & \multicolumn{2}{|c|}{385.37} \\
\hline dbh (cm) & \multicolumn{2}{|c|}{19.91} & \multicolumn{2}{|c|}{12.60} \\
\hline Light intensity (lux) & \multicolumn{2}{|c|}{7128.87} & \multicolumn{2}{|c|}{2629.12} \\
\hline Air temperature $\left({ }^{\circ} \mathrm{C}\right)$ & \multicolumn{2}{|c|}{18.02} & \multicolumn{2}{|c|}{21.97} \\
\hline Air relative humidity (\%) & \multicolumn{2}{|c|}{60.73} & \multicolumn{2}{|c|}{65.23} \\
\hline
\end{tabular}




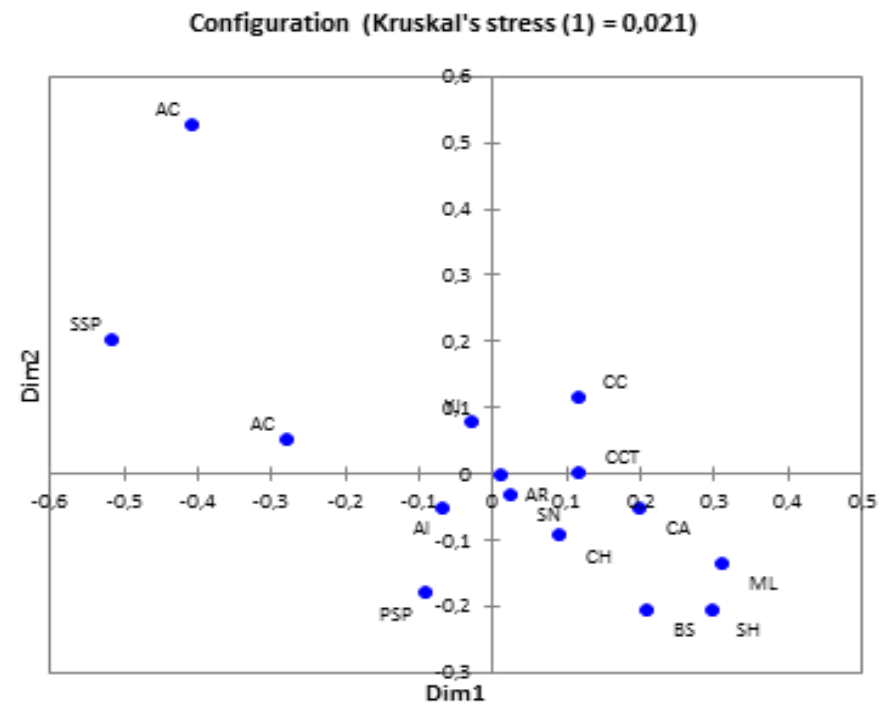

Figure 1. The multi-dimensional analysis result of three variables (air temperature, air relative humidity, and light intensity) of 13 exotic epiphyte that occurred on two tree fern species in CBG: C. junghuhniana and C. contaminans. SSP: S. ferox, SH: Strobilanthes hamiltoniana, AC1: Axonopus compressus, SN: Synedrella nodiflora, AC2: Ageratum conyzoides, BS: Bartlettina sordida, CC: Calliandra calothyrsus, PSP: Pennisetum sp., AR: Ageratina riparia, AI: Austroeupatorium inulaefolium, CA: Cestrum aurantiacum, CH: Clidemia hirta.

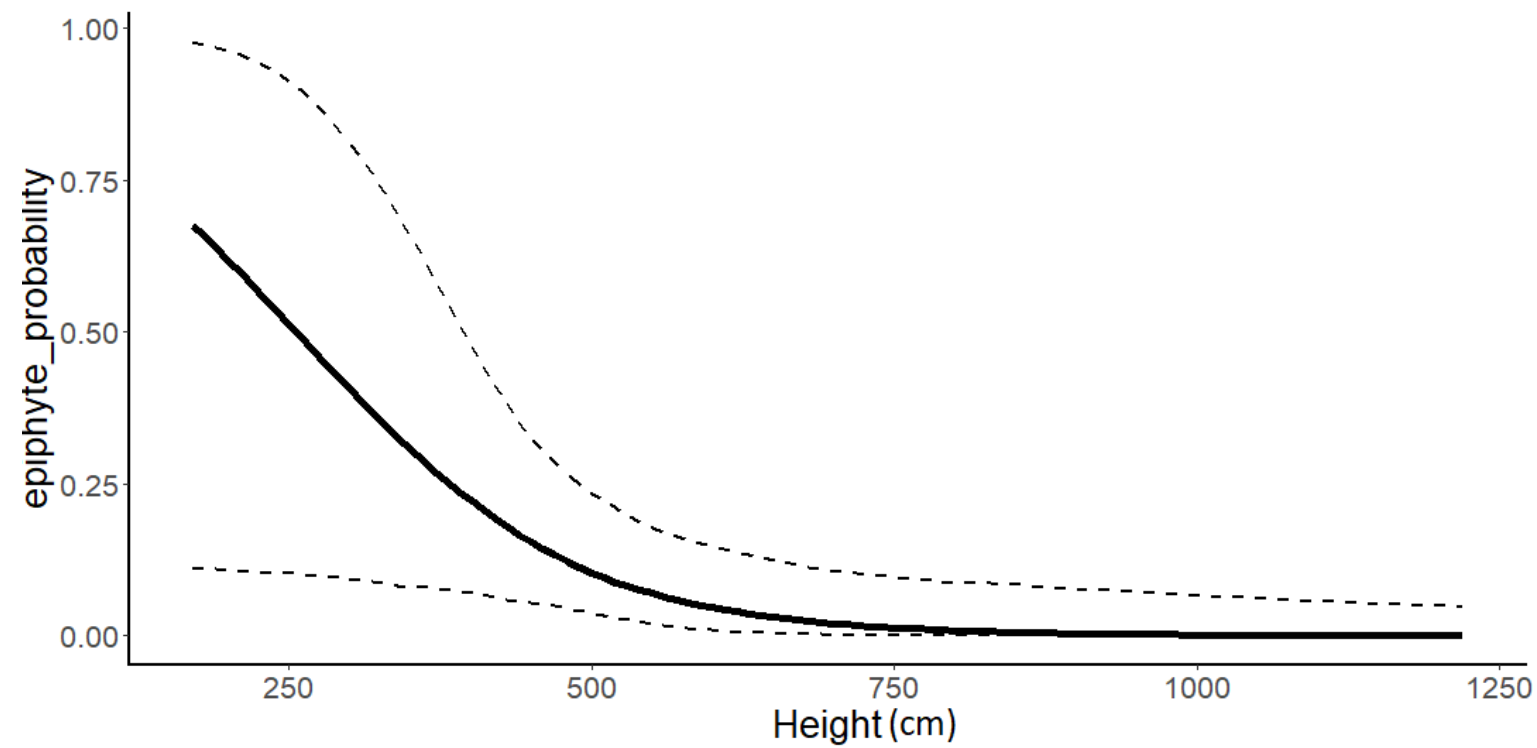

Figure 2. Predicted probability of Austroeupatorium inulaefolium to become exotic epiphyte on tree ferns across tree fern's height $(\mathrm{cm})$. The lower and upper dashed lines refer to $2.5 \%$ and $97.5 \%$ credible interval of the predictions respectively.

MDS analysis result showed that micro-climate preferences of $A$. compressus and $S$. ferox are very different from other exotic epiphytes (Figure 1). There are only four exotic epiphytes occurred on either $C$. contaminans or $C$. junghuh-niana. These four exotic epiphytes are A. inulaefolium, $A$. riparia, C. aurantiacum and C. hirta (Table 1 ).
Generally, Bayesian logistic regression analysis indicates no strong correlations between the occurrence probability of exotic epiphyte on tree ferns with explanatory variables for all abundant exotic epiphytes, except for $A$. inulaefolium.

Bayesian logistic regression result showed that the occurrence probability of $A$. inulaefolium as an 
exotic epiphyte on tree ferns in this study negatively correlated with the height of the tree ferns (mean $=-0.009$, credible interval $=[-0.018$, 0.0001]). Predicted occurrence probability of A. inulaefolium to become exotic epiphytes in tree ferns across tree fern's height showed that the probability reached nearly zero beyond $7.5 \mathrm{~m}$ (Figure 2). This figure may be explained by the facts that the seed of A. inulaefolium dispersed by wind and most of the source propagule located on the ground. This result may also indicate that $C$. junghuhniana is more suitable habitat than $C$. contaminans for $A$. inulaefolium because the later tree ferns species is significantly taller than the former one (t-test results: $\mathrm{p}$-value $=7.86 \times 10^{-8}$, height differences range $=[236 \mathrm{~cm}, 449 \mathrm{~cm}])$. Lastly, we detect no correlation between measured explanatory variables and the occurrence probability of the other abundant exotic epiphytes (Clidemia hirta and Ageratina riparia).

The light intensity did not explain the chance of exotic epiphyte's occurrence on tree ferns. These findings might be explained by several plausible explanations. First, the existence of exotic epiphyte on a tree fern's trunk was just the matter of stochastic event (random processes), it happened just by chance. Second, instead of light intensity, the light quality played a more important role on shaded plant species physiology. Chromatic light composition that reaches shaded epiphytes in the lower layer of tropical forest is different from the lights that reach the leaves on top canopy layer. A part of this light is already absorbed by top canopy leaves and the light composition already changed when it reaches lower layer canopy [22]. However, there are exotic species that exclusively occur on $C$. junghuhniana and $C$. contaminans (Table 1). Exotic epiphytes that only occur in $C$. junghuhniana are shade tolerant species because the light intensities for $C$. junghuhniana habitat are significantly lower than C. contaminans. In contrast, exclusive exotic epiphytes in C. contaminans are shade intolerant species.

The morphology of tree fern fronds is another factor that may affect the occurrence of exotic epiphytes. Older fronds of C. contaminans are caducous, leaving a pattern of the scar on the trunk, resulting in higher light penetration and unique trunk morphology. On the other hand, the fronds of $C$. junghuhniana are persistent, thus blocking the penetration of light. This blocked light situation under the canopy can affect the composition, diversity, and abundance of epiphytic plants. Furthermore, it also affects other microhabitat conditions such as water content in the root mantle of tree fern's trunk and air humidity that greatly affect the growth of epiphytic plants [11].

\section{Conclusion}

There are totally 13 exotic epiphyte species on native tree ferns $C$. junghuhniana and $C$. contaminans. Multi-dimensional analysis shows that $A$. compressus is very different from other exotic epiphytes due to its environmental preferences. A. riparia and $C$. hirta are exotic epiphytes that predicted to have a higher likelihood to become invasive and giving significant impacts to native ecosystems, therefore need to be prioritized for invasive species management. Lastly, the presence of A. inulaefolium as exotic epiphytes in tree ferns negatively correlated with the host's height. More study needed for these exotic epiphytes for tree fern host context. The more detailed model may be conducted by incorporate biological traits of the exotic epiphytes and more detail environmental parameters such as light chromatic quality. This kind of model may lead to clearer results on examining determinant factors that affect exotic species to become epiphyte on tree ferns or other host species in general.

\section{Acknowledgment}

Authors thank to the management of Cibodas Botanical Gardens for supporting this study through CBG In-House Research supports.

\section{References}

1. Davis MA, Chew MK, Hobbs RJ et al. (2011) Don't judge species on their origins. Nature 474: 153 - 154. doi: 10.1038/474153a.

2. Gurevitch J, Padilla DK (2004) Are invasive species a major cause of extinctions?. Trends in Ecology and Evolution 19 (9): 470 - 474. doi: 10.1016/j.tree.2004.07.005.

3. Parepa M, Fischer M, Bossdorf O (2013) Environmental variability promotes plant invasion. Nature Communications 4: 1604. doi: 10.1038/ncomms2632.

4. Mack RN, Simberloff D, Lonsdale WM et al. (2000) Biotic invasions: Causes, epidemiology, global consequences, and control. Ecological Applications 10 (3): 689 - 710. doi: 10.1890/1051-0761(2000)010[0689:BICEGC]2.0.CO;2.

5. CBD (2011) The targets 2011 - 2020. https://www.cbd.int/gspc/targets.shtml. Accessed: 30 Novem- 
ber 2015 .

6. Daehler CC (1998) The taxonomic distribution of invasive angiosperm plants: Ecological insights and comparison to agricultural weeds. Biological Conservation 84 (2): 167 - 180. doi 10.1016/S0006-3207(97)00096-7.

7. Werner FA, Homeier J, Gradstein, SR (2005) Diversity of vascular epiphytes on isolated remnant trees in the montane forest belt of southern Ecuador. Ecotropica 11: 21-40.

8. Bartels SF, Chen HY (2012) Mechanisms regulating epiphytic plant diversity. Critical Reviews in Plant Sciences 31 (5): 391 400. doi: 10.1080/07352689.2012.680349.

9. Bittner J, Trezos-Zelaya J (1997) Analysis of the vascular epiphytes of tree ferns in a montane rain forest in Costa Rica. Revista de Matematica: Teoria y Aplicaciones 4 (2): 63 - 73. doi 10.15517/rmta.v4i2.148.

10. Moran RC, Klimas S, Carlsen M (2003) Low-Trunk epiphytic ferns on tree ferns versus Angiosperms in Costa Rica. Biotropica 35 (1): 48 - 56. doi: 10.1646/0006-3606(2003)035[0048:LE FOTF]2.0.CO;2.

11. Roberts NR, Dalton PJ, Jordan GJ (2005) Epiphytic ferns and bryophytes of Tasmanian tree-ferns: A comparison of diversity and composition between two host species. Austral Ecology 30 (2): 146 - 154. doi: 10.1111/j.1442-9993.2005.01440.x.

12. Mutaqien Z, Zuhri M (2011) Establishing a long-term permanent plot in remnant forest of Cibodas Botanic Garden, West Java. Biodiversitas 12 (4): 218 - 224. doi: 10.13057/biodiv/d120406.

13. Van Steenis C, Hamzah A, Toha M (1972) Mountain flora of Java. Leiden, EJ Brill.
14. Yamada I (1975) Forest ecological studies of the montane forest of Mt Pangrango, West Java. 1. Stratification and floristic composition of the montane rain forest near Cibodas. South East Asian Studies 13: 402 - 426.

15. Pheloung PC, Williams PA, Halloy SR (1999) A weed risk assessment model for use as a biosecurity tool evaluating plant introductions. Journal of Environmental Management 57 (4): 239 - 251. doi: 10.1006/jema.1999.0297.

16. Team RC (2013) R: A language and environment for statistical computing. Vienna, Austria: R Foundation for Statistical Computing. http://www.R-project.org/. Accessed date: March 2018.

17. Plummer M (2003) JAGS: A program for analysis of Bayesian graphical models using Gibbs sampling. http://www.R-project.org/conferences/DSC-2003/. Accessed date: March 2018.

18. Kellner K (2015) A wrapper around 'rjags' to streamline 'JAGS' analyses. https://rdrr.io/cran/jagsUI/. Accessed date: March 2018.

19. Zotz G, Bermejo P, Dietz H (1999) The epiphyte vegetation of Annona glabra on Barro Colorado island, Panama. Journal of Biogeography 26 (4): 761 - 776. doi: 10.1046/j.1365-2699.19 99.00304.x.

20. Feng Y, Wang J, Sang W (2007) Biomass allocation, morphology and photosynthesis of invasive and noninvasive exotic species grown at four irradiance levels. Acta Oecologica 31 (1): 40 - 47. doi: 10.1016/j.actao.2006.03.009.

21. Gentry AH (1988) Changes in plant community diversity and floristic composition on environmental and geographical gradients. Annals of the Missouri Botanical Garden 75 (1): 1 - 34. doi: $10.2307 / 2399464$.

22. Luttge U (1997) Physiological ecology of tropical plants. Heidelberg, Springer Verlag. 
This page is intentionally left blank. 